\title{
A survey of dioxin-like contaminants in fish from recreational fishing
}

\author{
Eldbjørg Sofie Heimstad • Gaute Grønstøl • \\ Karl Torstein Hetland • Javier Martinez Alarcon • \\ Charlotta Rylander • Espen Mariussen
}

Received: 5 January 2015 / Accepted: 7 July 2015 / Published online: 19 July 2015

(C) The Author(s) 2015. This article is published with open access at Springerlink.com

\begin{abstract}
The dioxin and dioxin-like compounds are regarded as one of the most toxic group of environmental contaminants. Food for the commercial market is regularly monitored for their dioxin levels and the concentration allowed in food is strictly regulated. Less is known about locally caught fish from recreational fishing, which is often brought home for consumption. This can be fish caught from nearby lakes or streams or fish with marine origin close to industrial areas or harbours that are not regularly monitored for their dioxin levels. In this study, we established collaboration with schools in 13 countries. We received 203 samples of 29 different fish species of which Atlantic cod was the most abundant followed by brown trout and pollock. In general, the majority of samples from the participating countries had low concentrations (between 0.1 and $0.2 \mathrm{pg} / \mathrm{g}$
\end{abstract}

Electronic supplementary material The online version of this article (doi:10.1007/s10661-015-4728-7) contains supplementary material, which is available to authorized users.

\section{E. S. Heimstad $(\bowtie) \cdot$ C. Rylander}

NILU (Norwegian Institute for Air Research) FRAM - High

North Research Centre for Climate and the Environment,

NO-9296 Tromsø, Norway

e-mail: esh@nilu.no

G. Grønstøl

Centre of Schools' Science Education, University of Bergen,

Allégaten 41, NO-5007 Bergen, Norway

\section{K. T. Hetland}

Norwegian Centre for Science Education, P.O. Box 1099,

NO-0317 Blindern, Oslo, Norway chemical-activated luciferase gene expression toxic equivalency wet weight (CALUX TEQ w.w.)) of dioxins and dioxin-like PCBs. Only 18 samples had concentrations above $1 \mathrm{pg} / \mathrm{g}$ CALUX TEQ w.w., and only 2 dab samples had concentration above maximum levels set by the European Commission. The Atlantic cod samples showed a significant reduction in the concentrations of dioxins with increasing latitude indicating less contamination of dioxin and dioxin-like compounds in the north of Norway. The results indicate that a moderate consumption of self-caught fish at presumed non-contaminated sites does not represent a major risk for exposure to dioxins or dioxin-like compounds at concentrations associated with adverse health effects. Recreational fishermen should, however, obtain knowledge about local fish consumption advice.

J. M. Alarcon • E. Mariussen

NILU (Norwegian Institute for Air Research), P.O. Box 100, NO-2027 Kjeller, Norway

C. Rylander

Institute of Community Medicine, University of Tromsø, 9037 Tromsø, Norway

E. Mariussen

FFI (Norwegian Defence Research Establishment), P.O. Box 25, NO-2027 Kjeller, Norway 
Keywords Dioxins and dioxin-like contaminants . CALUX bioassay $\cdot$ Recreational fishing $\cdot$ Education . Cod $\cdot$ Pollock $\cdot$ Trout

\section{Introduction}

Persistent organic pollutants (POPs) have been shown to enter the food chains and accumulate in fat deposits, a process known as bioaccumulation, and thus become concentrated in organisms that prey upon lower organisms (Borga et al. 2005). This phenomenon has particularly been evident in remote ecosystems in polar regions, into which the pollutants have been transported with winds and ocean currents. POPs are also traced in common grocery goods, and consumers can unintentionally be exposed for instance by consuming farmed fish (Hites et al. 2004). The dioxins and dioxin-like compounds, such as chlorinated and brominated furans, are groups of POPs that are byproducts of industrial processes such as combustion of industrial waste. Other contaminants with dioxin-like toxicity are the coplanar polychlorinated biphenyls (PCBs) polychlorinated naphthalene (PCN) and polyaromatic hydrocarbons (PAHs). The dioxins and some of the dioxin-like compounds are considered to be the most toxic man-made contaminants known today, and they may have major impacts on human health (Mukerjee 1998; Humblet et al. 2008). The permitted levels of dioxins in food are strictly regulated in most countries, and a so-called toxic equivalent factor system (TEF) is established, which enables authorities to set guidelines for intake that do not exceed harmful levels (Van den Berg et al. 2006; Van den Berg et al. 1998). Fish are especially prone to accumulate POPs and most fish on the commercial market, both farmed and wild caught, are regularly monitored for their dioxin levels. Usually, an investigation of POPs in wild animals is restricted to certain areas and/or to certain animal species. Less is known about dioxin levels in locally caught fish from recreational fishing, which is often brought home for consumption. This can be fish caught from nearby lakes or streams or fish of marine origin close to industrial areas or harbours that are not regularly monitored for their dioxin levels. There are several practical challenges associated with making a national or worldwide screening of the dioxin levels in fish caught from recreational fishing, and the most significant is to obtain fish from an adequate number of areas. The international polar year (IPY) initiated by the Norwegian Research Council challenged the scientific environment in Norway to include different educational and outreach aspects in their research. In this study, we benefited from schools contributing with fish samples, data logging and their local knowledge about the region and habits for recreational fishing for food consumption. This enabled us to investigate trends and patterns in dioxin levels within and across fish species as well as across geographical regions. In addition, the study added some information about the risk of being exposed to dioxins and dioxin-like contaminants from consumption of self-caught fish. As far as we know, this project was one of the very few IPY projects where schools actively participated in a research project. Our experience with involving school students in environmental research shows that students are very attentive, meticulous and follow scientific instructions very carefully (Heimstad et al. 2003; Creilson et al. 2008; Nali and Lorenzini 2007).

\section{Materials and methods}

\section{Chemicals}

Hexane, dichloromethane, cyclohexane and toluene (gas chromatography grade, respectively), concentrated sulphuric acid, (analytical grade), sodium sulphate (anhydrous for analysis) and silica gel (0.063-0.200 mm, for column chromatography) were purchased from Merck (Germany). Diethyl ether (glass distilled grade) was purchased from Rathburn (Scotland). Isopropanol (chromosolv) and DMSO (for molecular biology) were purchased from Sigma. FBS Gold, defined foetal bovine serum, and Minimum Essential Medium (MEM) alpha modification were purchased from PAA laboratories (Germany). D-Luciferin was purchased from BioThema AB (Sweden). ATP was purchased from Saveen Werner $\mathrm{AB}$ (Sweden). The internal standards used for the chemical analysis of dioxins and PCBs in the study were from Cambridge Isotope Laboratories (CIL) and purchased from Promochem (Sweden). The dioxin standards used in the chemical-activated luciferase gene expression (CALUX) assay were purchased from Bio Detection Systems BV (Amsterdam). All other reagents used were analysis grade laboratory chemicals from standard commercial suppliers. 
Sampling of fish

An existing website, www.sustain.no, which is maintained and developed by the Norwegian Centre for Science Education, was used as a platform where the participating schools could log their data. This website is a resource for promoting training in sustainable development at all levels, from elementary to secondary school. In total, 54 schools from 13 countries participated in the project during the years 2007-2010. The majority of the 54 participating schools came from Norway (36 schools), followed by Estonia (4 schools), France (3 schools) and 1 or 2 schools from Australia, Croatia, Czech Republic, Denmark, Finland, Iceland, Latvia, Liechtenstein, Poland and Sweden. We received 206 fish samples (Table 1S). Three samples of common whitefish from a Swedish school were discarded due to doubt of the accuracy of the analysis. Details about the fish samples received for analyses are shown in supplementary materials (Table 1S). Each school received a protocol for handling their fish samples, ${ }^{1}$ which was carried out in accordance to the EMERGE sampling protocol (Rosseland et al. 2001). The species were identified, field data (GPS coordinates and description of field sampling site) were logged and weight and length of each individual fish were monitored. A muscle tissue sample was taken from the left side of the fish just above the pectoral fin and put into aluminium foil and frozen. The samples were then sent to NILU (Norwegian Institute for Air Research) and analysed for dioxins and dioxin-like compounds with the use of an in vitro bioassay (BDS DR CALUX ${ }^{\circledR}$ BioDetection System, The Netherlands) for Ah-receptor active compounds, such as dioxins and coplanar PCBs (Murk et al. 1996).

Analysis of dioxins and dioxin-like compounds by CALUX bioassay

Sample preparation and analysis of dioxins and dioxinlike compounds were performed according to the standard procedure of the manufacturer (Bio Detection Systems BV, Amsterdam, The Netherlands; Stronkhorst et al. 2002; Husain et al. 2014). Briefly, an aliquot of homogenized fish muscle samples $(\leq 0.5 \mathrm{~g}$ lipid) was mixed with $30 \mathrm{ml}$ ultra-pure water and isopropanol (1:1 v. v.) followed by an extraction with $30 \mathrm{ml}$ of hexane with $3 \%$ diethyl ether. The hexane fraction was transferred to

\footnotetext{
${ }^{1} \mathrm{http}: / /$ sustain.no/projects/globalpop/what_to_do.php
}

a clean pre-weighed glass vial and the extraction repeated three times. The hexane fractions were pooled and evaporated to dryness under a gently stream of nitrogen. The glass vial was weighed with the residues and the lipid content of the sample was estimated gravimetrically. The sample was resuspended in a small amount of hexane $(\sim 1 \mathrm{ml})$, and cleanup was performed on a multilayer acidic silica column (5 g of $33 \%$ sulphuric acid/silica followed by $5 \mathrm{~g}$ of $20 \%$ sulphuric acid/silica and $1 \mathrm{~cm}$ of anhydrous $\mathrm{Na}_{2} \mathrm{SO}_{4}$ ). The dioxins and dioxin-like compounds were eluted with $40 \mathrm{ml} n$-hexane with $3 \%$ diethyl ether. The cleaned extract was evaporated to near dryness and dissolved in DMSO to a final volume of $50 \mu \mathrm{L}$.

The DR CALUX analyses were performed by exposing a rat hepatoma H4IIE cell line stably transformed with an Ah-receptor controlled luciferase reporter gene. DR CALUX cells were obtained from Bio Detection Systems BV, Amsterdam, The Netherlands. The cells were cultured in $\alpha$-MEM culture medium supplemented with $10 \%(v / v)$ heat inactivated foetal calf serum at $37{ }^{\circ} \mathrm{C}, 5 \% \mathrm{CO}_{2}$ and $100 \%$ humidity. The cells were exposed to the fish extracts dissolved in DMSO in triplicates in 96-well plates for $24 \mathrm{~h}$ with a final DMSO concentration in the culture medium of $0.4 \%$. The $96-$ well plates also contained the standard 2,3,7,8-TCDD calibration solutions (0-20 pg TCDD per well), a DMSO blank and an additional reference sample of 2,3,7,8-TCDD. After exposure, the culture medium was removed, the cells were washed with PBS, and the cells were lysed with an aliquot of lysis buffer (10\% glycerol, $1 \%$ triton $\mathrm{x}-100,25 \mathrm{mM}$ Tris, $2 \mathrm{mM}$ DTT and 2 mM CDTA adjusted to pH 7.8). Luminescence was measured on a luminometer (BMG Lumistar Optima) by adding glowmix (33.3 mM DTT, $20 \mathrm{mM}$ trycin, $2.67 \mathrm{mM} \mathrm{MgSO} 4,1.07 \mathrm{mM} \mathrm{C}_{4} \mathrm{H}_{2} \mathrm{Mg}_{5} \mathrm{O}_{14}$, $530 \mu \mathrm{M}$ ATP, $470 \mu \mathrm{M}$ luciferin and $270 \mu \mathrm{M}$ coenzym A) to the lysed cell. The concentrations in the fish extract were calculated from the 2,3,7,8-TCDD calibration solution. Estimated limit of detection and limit (LOD) of quantification (LOQ) was $0.03 \pm 0.009$ (SD) and $0.09 \pm 0.03 \mathrm{pg} / \mathrm{g}$ CALUX toxic equivalency wet weight (TEQ w.w.)), respectively.

Chemical analysis of dioxins and dioxin-like compounds by gas chromatography high-resolution mass spectrometry

Extraction and cleanup were performed at NILU with a semi-automated three-column system as described in 
detail by Bengtson Nash et al. (2008). In brief, an aliquot of tissue was homogenized with anhydrous $\mathrm{Na}_{2} \mathrm{SO}_{4}$, spiked with internal standards (13C-labelled PCDD, PCDF and coplanar PCBs) and subjected to extraction and cleanup through three columns prepared with (a) activated silica and potassium silica, (b) silica and (c) activated carbon with dichloromethane (DCM) and cyclohexane (1:1) followed by DCM. Finally, the PCDD, PCDF and coplanar PCBs were eluted from the column with activated carbon with use of toluene. The toluene extracts were attributed to solvent exchange to hexane and further cleaned through consecutive sulphuric acidcoated silica column followed by potassium hydroxidecoated silica column with hexane followed by $1 \%$ DCM in hexane. 13C-labelled 1,2,3,4-TCDD recovery standard was added prior to analysis by HRGC-HRMSEI (an HP5890 GC coupled to a VG AutoSpec) by monitoring at $\mathrm{m} / \mathrm{z}$ of the molecular ions. The separation of the congeners was carried out on a DB-5 ms (30 m, $0.25 \mathrm{~mm}, 11 \mu \mathrm{m}$ film thickness) fused silica column.

\section{Data analysis}

Statistics (descriptive statistics, Mann-Whitney $U$, correlation analysis) were computed in GraphPad Prism 5 or Excel 2007. The non-parametric Mann-Mann-Whitney $U$ was used to compare the difference in the concentration of dioxin-like compounds between fish from northern and southern Norway separated at $63^{\circ}$ (cod and pollock) north and $60^{\circ}$ north (trout), respectively. To evaluate the accumulated levels of dioxin-like compounds in fish (cod, pollock and trout) as a function of latitude, the Pearson correlation analysis was used. Normal distribution in the variables was assessed using the D'Augostino and Pearson omnibus normality test. If necessary, $\log _{(10)}$ transformation was applied to obtain normality.

\section{Results and discussion}

Of the 203 submitted fish samples, 49 were Atlantic cod, which was the most common species in this study. All of the cod samples came from Norway (Table 1S). Brown trout and pollock were the second and third most abundant fish species with 31 and 26 samples, respectively. Nine of the 203 samples were quantified below LOQ, but all samples were quantified higher than LOD. In the statistical analysis, the measured concentrations of these samples were used even though they were below LOQ. Table 1 shows a summary of the measured CALUX TEQ in the collected fish on both wet weight (w.w.) and lipid weight (l.w.) concentration, in addition to size. Even though the dietary guidelines are based on wet weight concentrations of dioxins and dioxin-like PCBs, it can be convenient to report the concentrations of lipid-soluble compounds in fish in both wet weight and lipid weight, in order to do interspecies comparisons in accumulation. In general lipid-soluble compounds tend to accumulate in higher concentrations in fat fish compared to lean fish. Only one fish (7.4 CALUX TEQ/ g w.w.), a dab sample, had a concentration that was higher than the maximum limit set by the European Commission (EC 2011) for dioxins as a single group (3.5 pg TEQ/g w.w.) and for the sum of dioxins and dioxin-like PCBs (6.5 pg TEQ/g w.w.). To visualize the distribution of accumulated dioxin-like substances, the concentration data was separated in intervals of 0.1 units below $0.7 \mathrm{pg} \mathrm{TEQ} / \mathrm{g}$ w.w. and with larger intervals above 0.7 . The majority of samples had levels between 0.1 and $0.2 \mathrm{pg} / \mathrm{g}$ CALUX TEQ w.w. Only 12 samples had concentrations above $1 \mathrm{pg} / \mathrm{g}$ CALUX TEQ w. w. (Fig. 1). There were two samples of common dab from Norway with a high CALUX TEQ of 3.94 and $7.38 \mathrm{pg} / \mathrm{g}$ w.w., respectively. These two samples were caught at the harbour of Egersund, southwest of Norway. A survey by the National Institute of Nutrition and Seafood Research in Norway revealed that cod (liver) from this area had high levels of dioxin-like PCBs (Nilsen et al. 2011). The two dab samples were subjected to chemical analysis to get a detailed view of the content of dioxinlike compounds. The analyses revealed that the fish had even higher concentrations of dioxins and dioxin-like compounds than indicated by the bioassay, i.e., a sum WHO-TEQ 2005 of 6.72 and $13.76 \mathrm{pg} / \mathrm{g}$ w.w., respectively (Table 2). The CALUX bioassay is not a selective analytical method. All Ah-receptor inducers may in principle induce a response on the assay. These compounds include dioxins and furans, coplanar (dioxinlike) PCBs, PAHs and even PCN (Poland and Knutson 1982; Hanberg et al. 1991; Safe 1994; Okey 1990; Villeneuve et al. 2000). The sample preparation will, however, remove some of these substances, such as several of the PAHs. The possibility that there could have been compounds in the extracts that displayed antagonistic effects on the Ah-receptor should not be excluded. Comparative studies have shown that there are good correlations between traditional chemical 
Table 1 List of fish species, sorted on number of samples

\begin{tabular}{|c|c|c|c|c|c|c|}
\hline Fish species & Latin name & $\begin{array}{l}\text { CALUX TEQ } \\
\text { (pg/g w.w.) }\end{array}$ & $\begin{array}{l}\text { CALUX TEQ } \\
\text { (pg/g l.w.) }\end{array}$ & Weight (kg) & Length (cm) & Number $^{\mathrm{a}}$ \\
\hline \multirow[t]{2}{*}{ Atlantic cod } & \multirow[t]{2}{*}{ Gadus morhua } & $0.25(0.20)$ & $64(52)$ & $1.5(0.87)$ & $49(29)$ & \multirow[t]{2}{*}{$49(40)^{\mathrm{a}}$} \\
\hline & & $0.07-0.65$ & $18-180$ & $0.10-6.5$ & $6.6-78$ & \\
\hline \multirow[t]{2}{*}{ Brown trout } & \multirow[t]{2}{*}{ Salmo trutta } & $0.34(0.28)$ & $42(33)$ & $0.30(0.24)$ & $30(29)$ & \multirow[t]{2}{*}{$31(28)^{\mathrm{a}}$} \\
\hline & & $0.09-0.82$ & $10-140$ & $0.07-0.72$ & $16-42$ & \\
\hline \multirow[t]{2}{*}{ Pollock } & Pollachius pollachius & $0.20(0.15)$ & $40(36)$ & $1.4(1.3)$ & $54(39)$ & \multirow[t]{2}{*}{$26(23)$} \\
\hline & Pollachius virens & $0.07-0.54$ & $9.5-130$ & $0.18-3.4$ & $12-124$ & \\
\hline \multirow[t]{2}{*}{ European perch } & \multirow[t]{2}{*}{ Perca fluviatilis } & $0.24(0.16)$ & $48(40)$ & $0.08(0.08)$ & $18(19)$ & \multirow[t]{2}{*}{$14(6)$} \\
\hline & & $0.10-0.54$ & $21-89$ & $0.05-0.14$ & $13-23$ & \\
\hline \multirow[t]{2}{*}{ Arctic char } & \multirow[t]{2}{*}{ Salvelinus alpinus } & $0.49(0.48)$ & $45(40)$ & $0.45(0.29)$ & $40(31)$ & \multirow[t]{2}{*}{$10(10)$} \\
\hline & & $0.10-0.82$ & $19-145$ & $0.25-1.0$ & $28-90$ & \\
\hline \multirow[t]{2}{*}{ Common carp } & \multirow[t]{2}{*}{ Cyprinus carpio } & $0.43(0.32)$ & $30(18)$ & $1.5(1.4)$ & $42(43)$ & \multirow[t]{2}{*}{$6(6)$} \\
\hline & & $0.17-1.1$ & $6.6-104$ & $1.3-1.9$ & $37-49$ & \\
\hline \multirow[t]{2}{*}{ Pike } & \multirow[t]{2}{*}{ Esox lucius } & $0.35(0.27)$ & $130(65)$ & $0.81(0.89)$ & $47(47)$ & \multirow[t]{2}{*}{$6(5)$} \\
\hline & & $0.19-0.96$ & $51-310$ & $0.60-1.3$ & $45-50$ & \\
\hline \multirow[t]{2}{*}{ Flounder } & \multirow[t]{2}{*}{ Platichtys flesus } & $0.52(0.29)$ & $66(54)$ & n.d. & n.d & \multirow[t]{2}{*}{6} \\
\hline & & $0.27-1.1$ & $32-110$ & & & \\
\hline Atlantic mackerel & Scomber scombrus & $0.87(0.83)$ & $58(60)$ & $0.23(0.23)$ & $31(31)$ & $5(5)$ \\
\hline & & $0.18-1.7$ & $32-80$ & $0.20-0.26$ & $30-32$ & \\
\hline Haddock & Melanogrammus aeglefinus & $0.41(0.37)$ & $170(190)$ & $1.2(1.4)$ & $50(52)$ & $5(5)$ \\
\hline & & $0.06-1.1$ & $12-420$ & $0.4-2.1$ & $41-59$ & \\
\hline Fat chub & Leuciscus cephalus & $0.61(0.45)$ & $47(52)$ & $0.52(0.16)$ & $29(25)$ & $4(4)$ \\
\hline & & $0.13-1.4$ & $17-66$ & $0.13-1.6$ & $23-43$ & \\
\hline Mullet & Mugil cephalus & $0.43(0.46)$ & $170(170)$ & $1.2(1.2)$ & $47(48)$ & $4(4)$ \\
\hline & & $0.22-0.57$ & $80-260$ & $1.0-1.4$ & $40-50$ & \\
\hline Greater weever & Trachinus draco & $0.34(0.18)$ & $83(44)$ & $0.17(0.16)$ & $34(35)$ & $4(4)$ \\
\hline & & $0.14-0.84$ & $33-210$ & $0.14-0.22$ & $30-38$ & \\
\hline Gilthead bream & Sparus aurata & $2.9(1.0)$ & $2500(340)$ & 0.33 & 28 & $4(2)$ \\
\hline & & $0.42-9.1$ & $190-9100$ & & & \\
\hline Herring & Clupea harengus & $1.9(2.2)$ & $86(98)$ & 0.16 & 29 & $4(2)^{\mathrm{a}}$ \\
\hline & & $0.36-2.9$ & $17-130$ & & & \\
\hline Burbot & Lota lota & $0.23(0.20)$ & $28(29)$ & $0.43(0.38)$ & $36(38)$ & $3(3)$ \\
\hline & & $0.19-0.29$ & $18-35$ & $0.34-0.57$ & $33-38$ & \\
\hline Common dab & Limanda limanda & $3.9(3.9)$ & $83(89)$ & $0.37(0.37)$ & $32(32)$ & $3(3)$ \\
\hline & & $0.5-7.4$ & $65-97$ & $0.35-0.38$ & $31-33$ & \\
\hline Common whitefish & Coregonus lavaretus & $0.56(63)$ & $62(57)$ & $0.19(0.21)$ & $28(29)$ & $3(3)$ \\
\hline & & $0.36-0.68$ & $51-78$ & $0.17-0.21$ & $27-30$ & \\
\hline Roach & Rutilus rutilus & 0.2 & 28 & 0.07 & 15 & $2(1)$ \\
\hline Yellowfin bream & Acanthopagrus australis & 0.59 & 160 & n.d & n.d & 2 \\
\hline Narrowhead grey mullet & Mugil capurrii & 0.92 & 150 & n.d & n.d. & 2 \\
\hline Red mullet & Mullus surmuletus & 2.6 & 100 & n.d. & n.d. & 2 \\
\hline Red fish & Sebastes marinus & 1.1 & 22 & n.d. & n.d & 2 \\
\hline European plaice & Pleuronectes platessa & 0.14 & 18 & 0.56 & 37 & 1 \\
\hline Common ling & Molva molva & 0.54 & 150 & 4.3 & 85 & 1 \\
\hline Southern black bream & Acanthopagrus butcheri & 0.38 & 110 & 0.42 & 29 & 1 \\
\hline
\end{tabular}


Table 1 (continued)

\begin{tabular}{|c|c|c|c|c|c|c|}
\hline Fish species & Latin name & $\begin{array}{l}\text { CALUX TEQ } \\
\text { (pg/g w.w.) }\end{array}$ & $\begin{array}{l}\text { CALUX TEQ } \\
\text { (pg/g l.w.) }\end{array}$ & Weight $(\mathrm{kg})$ & Length $(\mathrm{cm})$ & Number $^{\mathrm{a}}$ \\
\hline Silver bream & Blicca bjoerkna & 1.3 & 130 & 0.12 & 19 & 1 \\
\hline Eel & Anguilla anguilla & 0.22 & 1.0 & 0.45 & 62 & 1 \\
\hline
\end{tabular}

The mean concentration of dioxin and dioxins-like compounds in muscle tissue shown as CALUX TEQ in a lipid weight (l.w.) and wet weight (w.w.) concentrations. The median concentrations are shown in brackets in addition to the minimum and maximum concentrations n.d. not determined

${ }^{\mathrm{a}}$ The number of samples with reported weight and length data

analyses and the CALUX bioassay (van Leeuwen et al. 2007; Scippo et al. 2004; Schoeters et al. 2004). Scippo et al. (2004) reported, however, a relatively large variation in the estimated TEQ values of the same samples when comparing between the bioassay and chemical analysis. Some samples had estimated a higher CALUX TEQ than the estimated TEQ from the chemical analysis and vice versa. The CALUX TEQ method is, however, very suitable as a screening tool to identify samples with high concentrations of Ah-receptor inducers. Since this is a first tier screening method for dioxin-like compounds, it is recommended that all suspect samples need to be analysed by high-resolution GC-MS analysis (Hoogenboom et al. 2006). Samples with high TEQ response near the maximum limit set by the European Commission should be further investigated with more reliable and quantitative methods such as traditional chemical analysis before potential dietary advices are established (Vromman et al. 2012).

Two of the fish samples (two dab samples) from Egersund harbour which had a high concentration of dioxin-like compounds measured with CALUX were

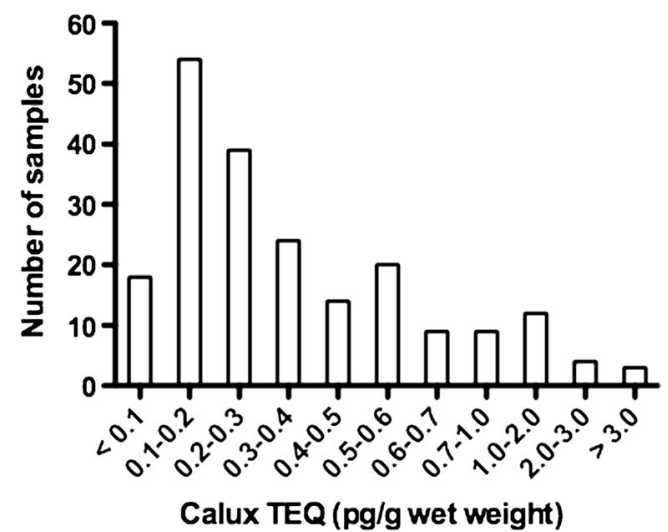

Fig. 1 Number of samples within increasing concentration intervals analysed by gas chromatography high-resolution mass spectrometry (GC HR-MS). The congener-specific analysis of the two dab samples showed highest concentration (pg/g w.w.) of PCB77, whereas PCB126 which has a TEF value of 0.1 , contributed to over $90 \%$ of the total measured TEQ concentration (Table 2). This is in accordance with previous studies showing that the coplanar dioxin-like PCBs are the dominating Ah-receptor inducers accumulated in marine organisms (e.g. Judd et al. 2004; van Leeuwen et al. 2007; Pandelova et al. 2008; Piskorska-Pliszczynska et al. 2012; Barone et al. 2014). This may be attributed to the ubiquitous spread of PCB due to their extensive industrial use, whereas the dioxins and furans are more regionally or locally distributed, as they are primarily by-products from combustion processes. Accordingly, fish from the Grenlands fjord in Norway, which have experienced extensive pollution from dioxins, have showed a higher proportion of the dioxins and furans contributing to the estimated TEQ-values (Knutzen et al. 2003). Also in juvenile dabs taken from various sites in Europe, it was found a higher proportion of the dioxins and furans contributing to the estimated TEQ values (Nunes et al. 2014).

Compared to similar studies that have used the CALUX bioassay method, the levels of dioxins in our samples were in general lower. We found 0.25 and $0.34 \mathrm{pg}$ CALUX TEQ/g w.w. in Atlantic cod and brown trout respectively, compared to 0.85 and $1.04 \mathrm{pg}$ CALUX TEQ/g w.w. in the same species from the Belgian market (Baeyens et al. 2007). Schoeters et al. (2004) reported a median concentration of $2.53 \mathrm{pg}$ CALUX TEQ/g w.w. in herring, whereas we found a concentration of $1.9 \mathrm{pg}$ CALUX TEQ/g w.w. van Leeuwen et al. (2007) analysed fish from the North Sea showing a median TEQ value of $0.6 \mathrm{pg} / \mathrm{g}$ w.w. in cod, between 0.8 and 
Table 2 The concentration of dioxins and dioxin-like compounds in muscle tissue in two dab samples shown as wet weight concentrations and as WHO-TEQ 2005

\begin{tabular}{|c|c|c|c|c|}
\hline Compound & Dab-1 & & Dab-2 & \\
\hline Dioxins & $\begin{array}{r}\text { Concentration } \\
\text { (pg/g w.w.) }\end{array}$ & $\begin{array}{l}\text { WHO-TEQ }_{2005} \\
\quad \text { (pg TEQ/g w.w.) }\end{array}$ & $\begin{array}{r}\text { Concentration } \\
\text { (pg/g w.w.) }\end{array}$ & $\begin{array}{l}\text { WHO-TEQ }_{2005} \\
\quad(\text { pg TEQ/g w.w.) }\end{array}$ \\
\hline 2378-TCDD & 0.67 & 0.67 & 0.34 & 0.34 \\
\hline 12378-PeCDD & 0.90 & 0.90 & 0.40 & 0.40 \\
\hline 123478-HxCDD & 0.11 & 0.01 & 0.05 & 0.005 \\
\hline 123678-HxCDD & 0.58 & 0.06 & 0.22 & 0.02 \\
\hline 123789-HxCDD & 0.13 & 0.01 & 0.07 & 0.007 \\
\hline 1234678-HpCDD & 0.38 & 0.004 & 0.28 & 0.003 \\
\hline OCDD & 0.58 & 0.0002 & 0.49 & 0.0001 \\
\hline SUM PCDD & 3.35 & 1.65 & 1.84 & 0.78 \\
\hline \multicolumn{5}{|l|}{ Furanes } \\
\hline 2378-TCDF & 10.6 & 1.06 & 5.79 & 0.58 \\
\hline 12378/12348-PeCDF & 1.16 & 0.03 & 0.61 & 0.02 \\
\hline 23478-PeCDF & 3.80 & 1.14 & 1.73 & 0.52 \\
\hline 123478/123479-HxCDF & 0.70 & 0.07 & 0.56 & 0.06 \\
\hline 123678-HxCDF & 0.49 & 0.05 & 0.35 & 0.04 \\
\hline 123789-HxCDF & 0.09 & 0.009 & 0.12 & 0.01 \\
\hline 234678-HxCDF & 0.37 & 0.04 & 0.19 & 0.02 \\
\hline 1234678-HpCDF & 0.72 & 0.007 & 0.87 & 0.009 \\
\hline 1234789-HpCDF & 0.22 & 0.002 & 0.34 & 0.003 \\
\hline OCDF & 1.27 & 0.0004 & 2.17 & 0.0007 \\
\hline SUM PCDF & 19.4 & 2.41 & 12.7 & 1.25 \\
\hline SUM PCDD/PCDF & 22.8 & 4.06 & 14.5 & 2.03 \\
\hline \multicolumn{5}{|l|}{ nonortho-PCB } \\
\hline 3344-ТеCB (PCB-77) & 484 & 0.05 & 306. & 0.03 \\
\hline 3445-ТeCB (PCB-81) & 26.2 & 0.008 & 15.5 & 0.005 \\
\hline 33445-PeCB (PCB-126) & 92.4 & 9.23 & 44.7 & 4.48 \\
\hline 334455-HxCB (PCB-169) & 13.5 & 0.40 & 5.8 & 0.17 \\
\hline SUM no-PCB & 616 & 9.70 & 373 & 4.69 \\
\hline Sum PCDD/PCDF/PCB & 639 & 13.76 & 388 & 6.72 \\
\hline
\end{tabular}

Samples were from the harbour of Egersund southwest of Norway

$2.4 \mathrm{pg} / \mathrm{g}$ w.w. in mackerel and 1.3 and $5.7 \mathrm{pg} / \mathrm{g}$ w.w. in herring. The somewhat higher concentrations in fish from these studies may be attributed to the area of catch and size of the fish. A summary of concentrations of dioxins and dioxin-like compounds in different fish species caught in European waters relevant to our study are provided in Table 3. Here, it is evident that there are large variations both between and within species due to various fat content and geographical locations (Table 3). Our findings corroborate, however, the general findings that most fish have dioxin concentrations below the levels recommended by the European Commission (EC 2011).

The northern parts of Europe (for instance above the $63^{\circ}$ north parallel line) are less industrialized than the south, and even though a substantial long-range transport of contaminants to Arctic areas do occur, studies have found that fish from the northern areas in general are less contaminated by dioxins and PCBs than fish from the southern areas (Wania 1999; Wania and Su 2004). However, exceptions exist, for instance in the Gulf of Bothnia 
Table 3 Data on concentrations of dioxins and dioxin-like compounds in fish from European waters

\begin{tabular}{|c|c|c|c|c|}
\hline Species & Origin & Year & pg TEQ/g w.w. & Reference \\
\hline Eel & Belgian market & 2004-2006 & $1.16 \pm 0.61^{\mathrm{a}}$ & Baeyens et al. (2007) \\
\hline Eel & Ebro river Spain & 2012 & $1.81^{\mathrm{b}}$ & Parera et al. (2013) \\
\hline Eel & Southwest Italy & 2008-2009 & $0.91-11.4^{\mathrm{c}}$ & Pacini et al. (2013) \\
\hline Eel & Grenland fjords & $2000-2001$ & $26.2 ; 27.7^{\mathrm{c}}$ & Knutzen et al. (2003) \\
\hline Eel & Latvian lakes & 2009 & $6.70^{\mathrm{b}}$ & Zacs et al. (2013) \\
\hline Cod & Belgian market & 2004-2006 & $0.85 \pm 0.64^{\mathrm{a}}$ & Baeyens et al. (2007) \\
\hline Cod & Polish Baltic sea & 2009-2010 & $0.85-0.86^{\mathrm{b}}$ & Piskorska-Pliszczynska et al. (2012) \\
\hline Cod & Baltic sea & 2009-2011 & $0.87-0.89^{\mathrm{b}}$ & Struciński et al. (2013) \\
\hline Cod & North Sea & 2000 & $0.3-0.8^{\mathrm{c}}$ & van Leeuwen et al. (2007) \\
\hline Cod & Grenland fjords & $2000-2001$ & $1.9^{\mathrm{c}}$ & Knutzen et al. 2003 \\
\hline Cod & North Sea & 1995-1997 & $0.024-0.074^{\mathrm{e}}$ & Karl et al. 2002 \\
\hline Brown trout & Belgian market & 2004-2006 & $1.04 \pm 0.67^{\mathrm{a}}$ & Baeyens et al. (2007) \\
\hline Brown trout & Southwest Italy & 2008-2009 & $0.22^{\mathrm{c}}$ & Pacini et al. (2013) \\
\hline Herring & English channel & $2000-2004$ & $1.3-5.7^{\mathrm{c}}$ & van Leeuwen et al. (2007) \\
\hline Herring & Belgian market & 2004-2006 & $1.41 \pm 0.4^{\mathrm{a}}$ & Baeyens et al. (2007) \\
\hline Herring & Gulf of Finland & 2005 & $2.19-2.47^{\mathrm{b}}$ & Pandelova et al. (2008) \\
\hline Herring & Baltic sea & $2002-2006$ & $3.4-7.0^{\mathrm{b}}$ & Szlinder-Richert et al. (2009) \\
\hline Herring & Baltic sea & 2006-2011 & $1.19-7.28^{\mathrm{b}}$ & Struciński et al. (2013) \\
\hline Herring & Polish Baltic sea & $2006-2010$ & $2.63-4.45^{\mathrm{b}}$ & Piskorska-Pliszczynska et al. (2012) \\
\hline Herring & Norwegian Sea & 2006-2007 & $0.24-3.5^{\mathrm{b}}$ & Frantzen et al. (2011) \\
\hline Herring & Belgian market & $2000-2001$ & $2.53^{\mathrm{ad}}$ & Schoeters et al. (2004) \\
\hline Herring & Grenland fjords & $2000-2001$ & $12.1^{\mathrm{c}}$ & Knutzen et al. (2003) \\
\hline Flounder & Ebro river Spain & 2012 & $1.11^{\mathrm{b}}$ & Parera et al. (2013) \\
\hline Flounder & Baltic sea & 2004 & $0.53-1.63^{\mathrm{b}}$ & Pandelova et al. (2008) \\
\hline Flounder & Grenland fjords & $2000-2001$ & $3.5 ; 33.5^{\mathrm{c}}$ & Knutzen et al. (2003) \\
\hline Common carp & Southwest Italy & 2008-2009 & $1.18-1.74^{\mathrm{c}}$ & Pacini et al. (2013) \\
\hline Common carp & Latvian lakes & 2009 & $0.06 ; 0.16^{\mathrm{b}}$ & Zacs et al. (2013) \\
\hline Fat chub & Southwest Italy & 2008-2009 & $0.40-2.62^{\mathrm{c}}$ & Pacini et al. (2013) \\
\hline Fat chub & Latvian lakes & 2009 & $0.36^{\mathrm{b}}$ & Zacs et al. (2013) \\
\hline Perch & Peipsi, Estonia & 2004 & $0.185-0.303^{\mathrm{b}}$ & Pandelova et al. (2008) \\
\hline Perch & Gulf of Finland & 2004 & $0.32-1.37^{\mathrm{b}}$ & Pandelova et al. (2008) \\
\hline Perch & Gulf of Riga & 2004 & $0.868-1.605^{\mathrm{b}}$ & Pandelova et al. (2008) \\
\hline Perch & Latvian lakes & 2009 & $0.12 ; 2.06^{\mathrm{b}}$ & Zacs et al. (2013) \\
\hline Roach & Latvian lake & 2009 & $0.21^{\mathrm{b}}$ & Zacs et al. (2013) \\
\hline Pike & Latvain lake & 2009 & $0.15^{\mathrm{b}}$ & Zacs et al. (2013) \\
\hline Mackerel & Spain market & 2005 & $1.12^{\mathrm{b}}$ & Bocio et al. (2007) \\
\hline Mackerel & North Sea & $2000-2004$ & $0.8-2.4^{\mathrm{c}}$ & van Leeuwen et al. (2007) \\
\hline Mackerel & Belgian market & $2000-2001$ & $0.36^{\mathrm{ad}}$ & Schoeters et al. (2004) \\
\hline Mackerel & Bay of Biscaya & 1995-1998 & $0.15-0.66^{\mathrm{e}}$ & Karl et al. (2002) \\
\hline Mackerel & Grenland fjords & $2000-2001$ & $7.4^{\mathrm{c}}$ & Knutzen et al. (2003) \\
\hline Red mullet & Spain market & 2005 & $4.65^{\mathrm{b}}$ & Bocio et al. (2007) \\
\hline
\end{tabular}


Table 3 (continued)

\begin{tabular}{lllll}
\hline Species & Origin & Year & pg TEQ/g w.w. & Reference \\
\hline Plaice & Belgian market & $2000-2001$ & $0.34^{\text {ad }}$ & Schoeters et al. (2004)
\end{tabular}

${ }^{\mathrm{a}}$ CALUX TEQ

${ }^{\mathrm{b}}$ WHO-TEQ 2005 total

${ }^{\mathrm{c}}$ WHO-TEQ 1997 total

${ }^{\mathrm{d}}$ Median concentration

${ }^{\mathrm{e}} \mathrm{WHO}_{1995}$-PCDD/F TEQ

where dietary advices exist for herring and other fish species due to high levels of dioxins and dioxin-like PCBs. We compared the CALUX TEQ in fish caught north and south of $63^{\circ}$ north. The most abundant fish species in our
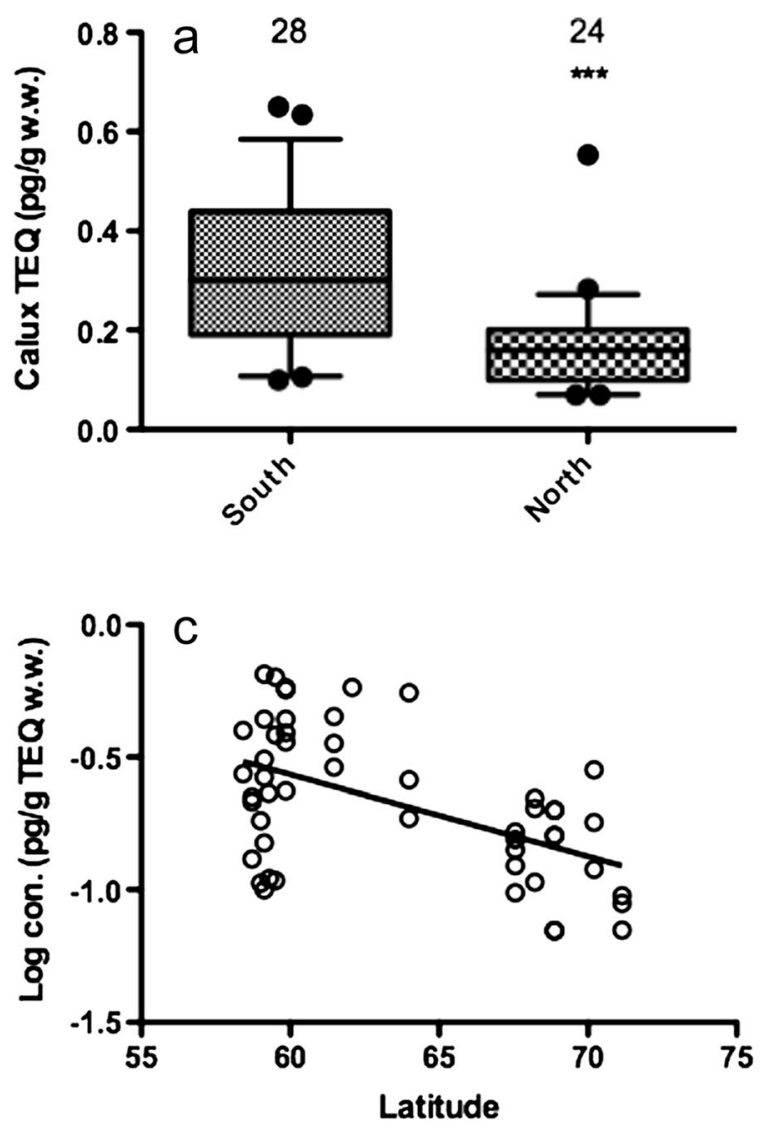

Fig. 2 Box plots of the concentration (max and min indicate the 10 and $90 \%$ percentile and numbers of samples) on wet weight (a) and lipid weight (b) concentrations of dioxins and dioxin-like compounds between Atlantic cod from northern and southern Norway separated $63^{\circ}$ north. Asterisks indicate statistical significant difference between groups (Mann-Whitney $U * p<0.05$; sample was the marine species Atlantic cod. Cod caught north of $63^{\circ}$ north showed a significantly lower average CALUX TEQ value (Mann-Whitney $U, p<0.001$ w.w.; $p<0.05$ l.w.) than fish caught further south (Fig. 2).
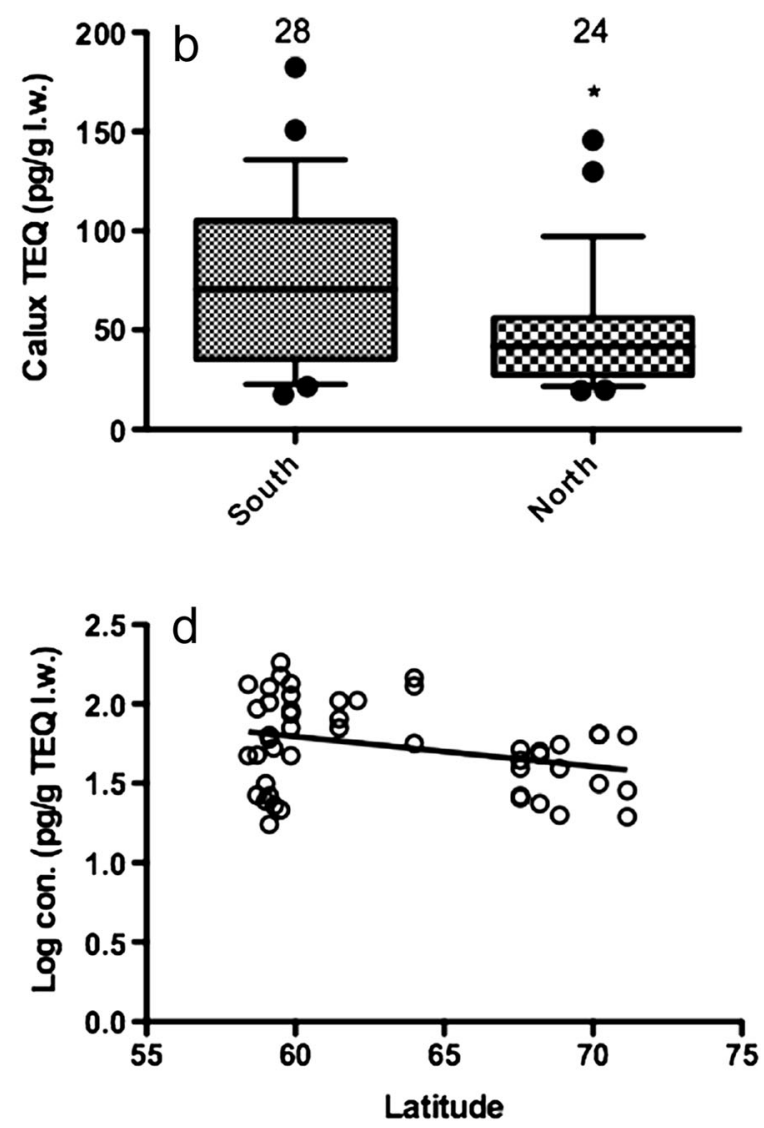

***p $<0.001)$. The concentrations are also shown by latitude of trapping site $(\mathbf{c}, \mathbf{d})$. Correlation analyses also showed that dioxin concentration decreased with increasing latitude (Pearson rank correlation $\left(r_{\mathrm{p}}\right)$ w.w. $=-0.53 p<0.0001, R^{2} 0.28 ; r_{\mathrm{p}}$ l.w. $=-0.31$ $\left.p<0.03, R^{2} 0.098\right)$ 


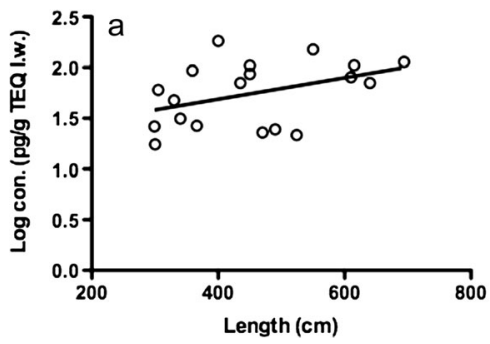

Fig. 3 The log transformed concentration of dioxins and dioxinlike compounds in Atlantic cod on wet weight (a) and lipid weight (b) concentrations from the southern parts of Norway (south of $63^{\circ}$

Correlation analyses also showed that dioxin concentration decreased with increasing latitude (Pearson rank correlation $\left(r_{\mathrm{p}}\right)$ w.w. $=-0.53 p<0.0001 ; r_{\mathrm{p}}$ l.w. $\left.=-0.31 p<0.03\right)$.

\section{Pollock}

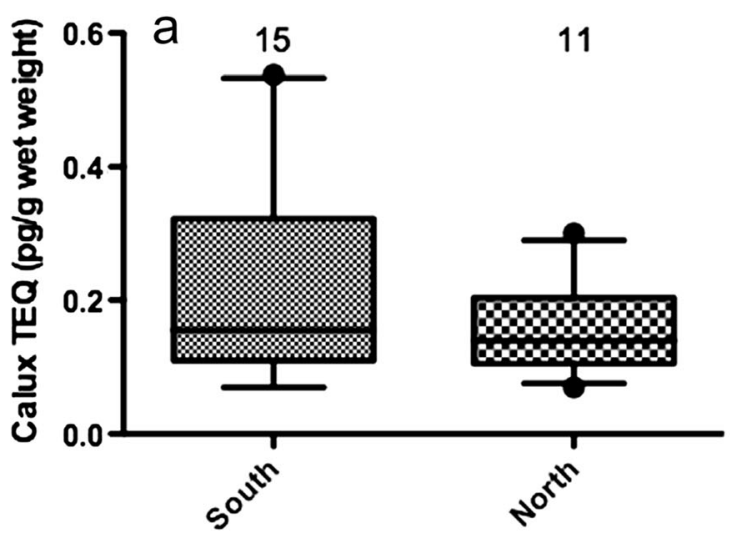

Trout

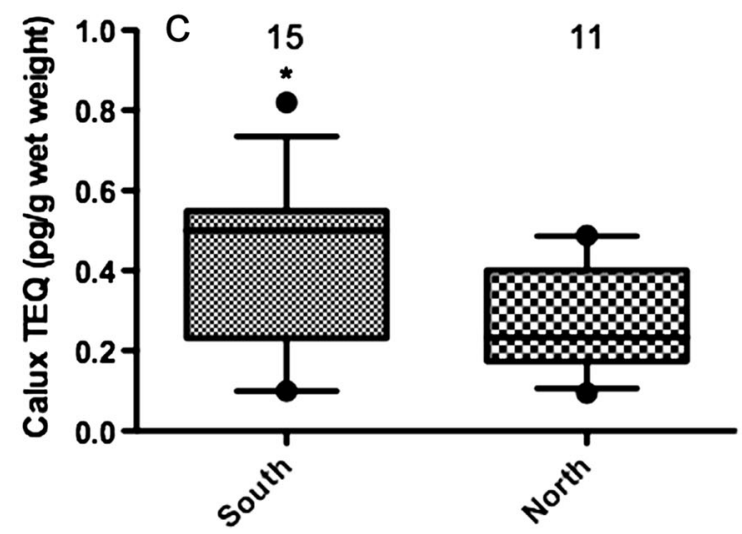

Fig. 4 A box plot of the concentration (max and min indicate the 10 and $90 \%$ percentile and numbers of samples) of dioxins and dioxin-like compounds on wet weight and lipid weight concentrations of pollock $(\mathbf{a}, \mathbf{b})$ and brown trout $(\mathbf{c}, \mathbf{d})$ from northern and

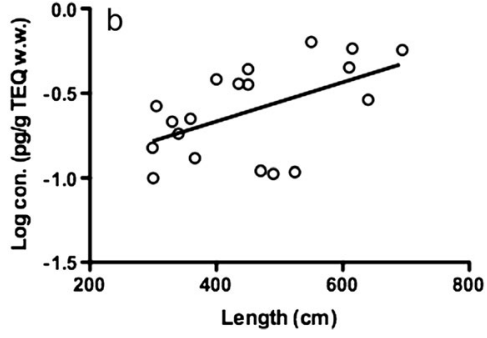

north) Correlation analysis showed a significant increase in the dioxin concentration with fish length for the wet weight concentration analyses $\left(r_{\mathrm{p}}\right.$ w.w. $\left.=0.53, p<0.02, R^{2} 0.28\right)$

Fish length is typically directly related to age, so within a species, larger fish in general represents older fish. Older fish also tend to have higher loads of
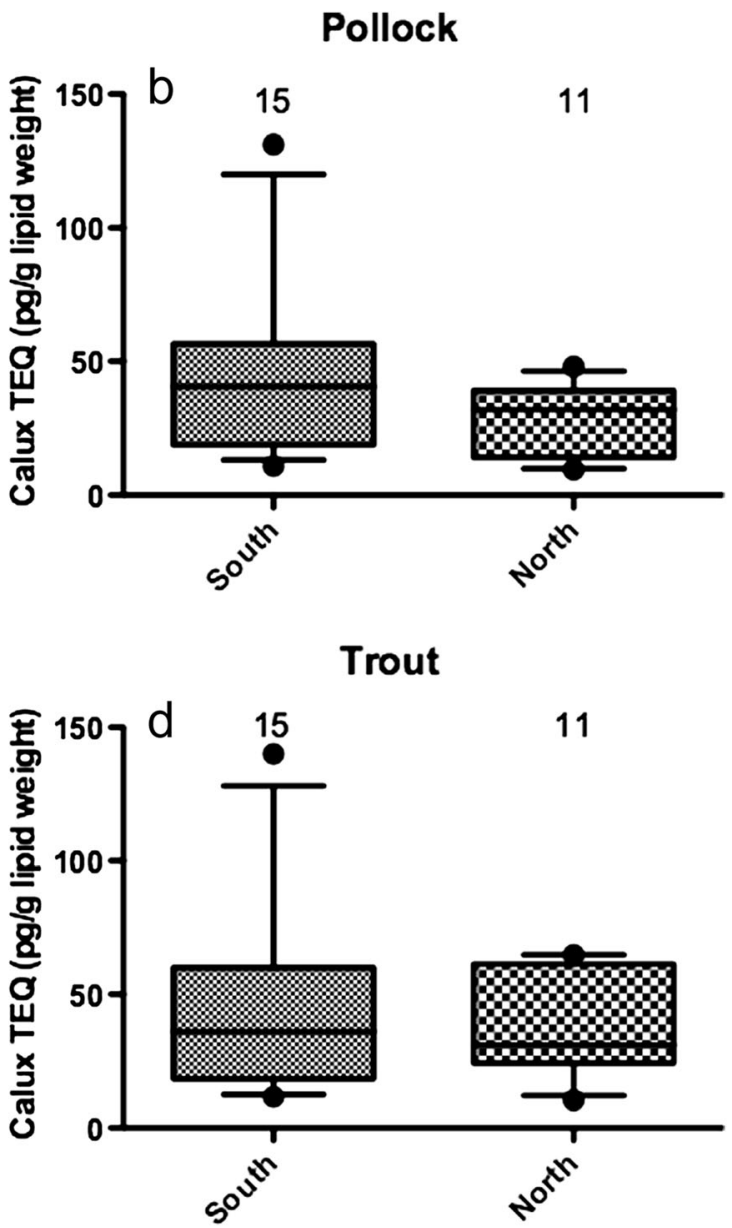

southern Norway separated at $63^{\circ}$ north and $60^{\circ}$ north, respectively. Asterisk indicates statistical significant difference between groups (Mann-Whitney $U^{*} p<0.05$ ) 
contaminants due to bioaccumulation over time. The north Norwegian fish was in general longer than fish from the south. In cod from southern Norway, fish length correlated significantly with the CALUX TEQ levels on the wet weight concentration $\left(r_{\mathrm{p}}\right.$ w.w. $=0.53$, $p<0.02)$ and close to significantly on the lipid weight concentration $\left(r_{\mathrm{p}}\right.$ l.w. $\left.=0.41, p=0.08\right)($ Fig. 3$)$. This was not observed in fish from the northern part of Norway $\left(r_{\mathrm{p}}\right.$ w.w. $=-0.016, p<0.94 ; r_{\mathrm{p}}$. 1.w. $\left.=-0.14, p=0.50\right)$. We also compared the pollock caught north and south of $63^{\circ}$ north and the trout caught north and south of $60^{\circ}$ north (Fig. 4). For the pollock samples, the difference in the CALUX TEQ concentration was near significant on the lipid weight concentration ( $p=0.078$, MannWhitney $U$ ) and for the trout samples only on wet weight concentration ( $p<0.05$, Mann-Whitney $U$ ). The CALUX TEQ concentrations showed a nonsignificant correlating trend $f$ with the latitude for both of the species (data not shown). The sampling sites from south Norway were fjord areas closer to cities and more densely populated than the sampling sites in the north (Table 1S). This may explain the higher CALUX TEQ concentrations of the fish from south Norway compared to north Norway. In support of this, the two samples of common dab caught in the Egersund harbour in southwest Norway exhibited CALUX TEQ levels above maximum levels (EC 2011). Further, these two dab samples had relatively high fat content compared to other fish from the same area with lower TEQ concentrations (sea trout, pollock and a lean dab sample). In addition, common dabs are bottom-feeding fish and dioxins and PCBs are known to adsorb to sediments (Persson et al. 2002; Cornelissen et al. 2008).

\section{Conclusions}

The majority of fish samples from the participating countries had concentrations of dioxins and dioxin-like compounds lower than the maximum limits set by the European commission. The findings are in accordance with other surveys of dioxins in fish from European waters. The CALUX TEQ levels in the cod samples showed a significant reduction in the concentrations of dioxins with increasing latitude, indicating less contamination of dioxin and dioxin-like compounds in the north. Our results indicate that a moderate consumption of self-caught fish from presumed non-contaminated sites does not represent any major risk for exposure to dioxins or dioxin-like compounds at concentrations associated with adverse health effects. Previous reports have however showed that high-level fish consumers, or consumption of fish from contaminated sites, may exceed recommended guidelines (e.g. Judd et al. 2004; Harris and Jones 2008.). In the Norwegian Mother and Child Cohort Study by Papadopoulou et al (2013), it was shown that dietary intake of dioxins and PCBs during pregnancy were negatively associated with foetal growth, even at intakes below the tolerable weekly intake of $14 \mathrm{pg} \mathrm{TEQ} / \mathrm{kg}$ bw. One should also be aware of other contaminants in fish, such as mercury and noncoplanar PCBs. Elevated levels of mercury are reported in hair from recreational fishermen (Lincoln et al. 2011) and exposure to mercury from fish is associated with adverse health effects (e.g. Karagas et al. 2012). Even in fish caught at a remote site, the levels of mercury may exceed the guidelines for commercial sale (Evans et al. 2005). The non-coplanar PCBs are accumulated in higher concentrations in fish than the coplanar dioxin-like PCBs (Barone et al. 2014), and it has been claimed that the use of toxic equivalency factors that are based on dioxin-like activity is inadequate for estimating the total risk from exposures to PCBs (Fischer et al. 1998). In the study by Harris and Jones (2008), it was reported that $18 \%$ had no knowledge about fish advisories in VA, USA. Recreational anglers should therefore obtain knowledge about local fish consumption advice.

Acknowledgments We would like to express our gratitude to all the enthusiastic teachers who have arranged fishing field trips and inspired their students to do scientific work, to pose their own questions and to formulate own answers and conclusions. Finally, we will say to the school students: "We are impressed over your enthusiasm and skills as real scientific researchers, and hope to work with you in the future!" We are grateful for the financial support from the Research Council of Norway, project 18218: "A global network of schools investigating environmental pollutants in fish from the Arctic and worldwide" and for the kind assistance of Bio Detection Systems BV, The Netherlands.

Open Access This article is distributed under the terms of the Creative Commons Attribution 4.0 International License (http:// creativecommons.org/licenses/by/4.0/), which permits unrestricted use, distribution, and reproduction in any medium, provided you give appropriate credit to the original author(s) and the source, provide a link to the Creative Commons license, and indicate if changes were made. 


\section{References}

Baeyens, W., Leermakers, M., Elskens, M., Van Larebeke, N., De Bont, R., Vanderperren, H., Fontaine, A., Degroodt, J. M., Goeyens, L., Hanot, V., \& Windal, I. (2007). PCBs and PCDD/FS in fish and fish products and their impact on the human body burden in Belgium. Archives of Environmental Contamination and Toxicology, 52, 563-571.

Barone, G., Giacominelli-Stuffler, R., Garofalo, R., Castiglia, D., \& Storelli, M. M. (2014). PCBs and PCDD/PCDFs in fishery products: occurrence, congener profile and compliance with European Union legislation. Food and Chemical Toxicology, 74, 200-205.

Bengtson Nash, S. M., Poulsen, A. H., Kawaguchi, S., Vetter, W., \& Schlabach, M. (2008). Persistent organohalogen contaminant burdens in Antarctic krill (Euphausia superba) from the eastern Antarctic sector: a baseline study. Science of the Total Environment, 407, 304-314.

Bocio, A., Domingo, J. L., Falcó, G., \& Llobet, J. M. (2007). Concentrations of PCDD/PCDFs and PCBs in fish and seafood from the Catalan (Spain) market: estimated human intake. Environmental International, 33, 170-175.

Borga, K., Fisk, A. T., Hargrave, B., Hoekstra, P. F., Swackhamer, D., \& Muir, D. C. (2005). Bioaccumulation factors for PCBs revisited. Environmental Science \& Technology, 39, 45234532 .

Cornelissen, G., Wiberg, K., Broman, D., Arp, H. P., Persson, Y., Sundqvist, K., \& Jonsson, P. (2008). Freely dissolved concentrations and sediment-water activity ratios of PCDD/Fs and PCBs in the open Baltic Sea. Environmental Science and Technology, 42, 8733-8739.

Creilson, J. K., Pippin, M. R., Henderson, B. L., Ladd, I. H., Fishman, J., Votápková, D., \& Krpcová, I. (2008). Surface ozone measured at globe schools in the Czech Republic-a demonstration of the importance of student contribution to the larger science picture. Bulletin of the American Meteorological Society, 89, 505-514.

EC 2011. COMMISSION REGULATION (EU) No 1259/2011 of 2 December 2011 amending Regulation (EC) No 1881/2006 as regards maximum levels for dioxins, dioxin-like PCBs and non dioxin-like PCBs in foodstuffs. http://eur-lex.europa.eu/ L e x U r i S e r v/ L e x U r i S e r v. d o ? u r i = OJ:L:2011:320:0018:0023:EN:PDF

Evans, M. S., Lockhart, W. L., Doetzel, L., Low, G., Muir, D., Kidd, K., Stephens, G., \& Delaronde, J. (2005). Elevated mercury concentrations in fish in lakes in the Mackenzie River Basin: the role of physical, chemical, and biological factors. Science of the Total Environment, 351-352, 479-500.

Fischer, L. J., Seegal, R. F., Ganey, P. E., Pessah, I. N., \& Kodavanti, P. R. (1998). Symposium overview: toxicity of non-coplanar PCBs. Toxicological Sciences, 41, 49-61.

Frantzen, S., Måge, A., Iversen, S. A., \& Julshamn, K. (2011). Seasonal variation in the levels of organohalogen compounds in herring (Clupea harengus) from the Norwegian Sea. Chemosphere, 85, 179-187.

Hanberg, A., Ståhlberg, M., Georgellis, A., de Wit, C., \& Ahlborg, U. G. (1991). Swedish dioxin survey: evaluation of the H-4-II E bioassay for screening environmental samples for dioxinlike enzyme induction. Pharmacology \& Toxicology, 69, 442-449.
Harris, S. A., \& Jones, J. L. (2008). Fish consumption and PCBassociated health risks in recreational fishermen on the James River, Virginia. Environmental Research, 107, 254-263.

Heimstad, E. S., Herzke, D., Endregard, G., \& Hetland, K. (2003). Circumpolar investigation of brominated diphenyl ethersconnecting research and education. Organohalogen Compounds, 61, 65-68.

Hites, R. A., Foran, J. A., Carpenter, D. O., Hamilton, M. C., Knuth, B. A., \& Schwager, S. J. (2004). Global assessment of organic contaminants in farmed salmon. Science, 303, 226-229.

Humblet, O., Birnbaum, L., Rimm, E., Mittleman, M. A., \& Hauser, R. (2008). Dioxins and cardiovascular disease mortality. Environmental Health Perspectives, 116, 1443-1448.

Hoogenboom, L., Traag, W., Bovee, T., Goeyens, L., Carbonnelle, S., Van Loco, J., Beernaert, H., Jacobs, G., Schoeters, G., \& Baeyens, W. (2006). The CALUX bioassay: current status of its application to screening food and feed. Trends in Analytical Chemistry, 25, 410-420.

Husain, A., Gevao, B., Dashti, B., Brouwer, A., Behnisch, P. A., AlWadi, M., \& Al-Foudari, M. (2014). Screening for PCDD/Fs and dl-PCBs in local and imported food and feed products available across the State of Kuwait and assessment of dietary intake. Ecotoxicology and Environmental Safety, 100, 27-31.

Judd, N., Griffith, W. C., \& Faustman, E. M. (2004). Contribution of PCB exposure from fish consumption to total dioxin-like dietary exposure. Regulatory Toxicology and Pharmacology, 40, 125-135.

Karagas, M. R., Choi, A. L., Oken, E., Horvat, M., Schoeny, R., Kamai, E., Cowell, W., Grandjean, P., \& Korrick, S. (2012). Evidence on the human health effects of low-level methylmercury exposure. Environmental Health Perspectives, 120, 799-806.

Karl, H., Ruoff, U., \& Blüthgen, A. (2002). Levels of dioxins in fish and fishery products on the German market. Chemosphere, 49, 765-773.

Knutzen, J., Bjerkeng, B., Naes, K., \& Schlabach, M. (2003). Polychlorinated dibenzofurans/dibenzo-p-dioxins (PCDF/ PCDDs) and other dioxin-like substances in marine organisms from the Grenland fjords, S. Norway, 1975-2001: present contamination levels, trends and species specific accumulation of PCDF/PCDD congeners. Chemosphere, 52, 745-760.

Lincoln, R. A., Shine, J. P., Chesney, E. J., Vorhees, D. J., Grandjean, P., \& Senn, D. B. (2011). Fish consumption and mercury exposure among Louisiana recreational anglers. Environmental Health Perspectives, 119, 245-251.

Nunes, M., Martinho, F., Vernisseau, A., Marchand, P., Le Bizec, B., van der Veer, H. W., Cabral, H. N., Ramos, F., \& Pardal, M. A. (2014). Early contamination of European flounder (Platichthys flesus) by PCDD/Fs and dioxin-like PCBs in European waters. Marine Pollution Bulletin, 85, 292-296.

Mukerjee, D. (1998). Health impact of polychlorinated dibenzo-pdioxins: a critical review. Journal of Air Waste Management, $48,157-165$.

Murk, A. J., Legler, J., Denison, M. S., Giesy, J. P., van de Guchte, C., \& Brouwer, A. (1996). Chemical-activated luciferase gene expression (CALUX): a novel in vitro bioassay for Ah receptor active compounds in sediments and pore water. Fundamental and Applied Toxicology, 33, 149-160.

Nali, C., \& Lorenzini, G. (2007). Air quality survey carried out by schoolchildren: an innovative tool for urban planning. Environmental Monitoring and Assessment, 131, 201-210. 
Nilsen, B. M., Frantzen, S., \& Julshamn, K. (2011). Fremmedstoffer i villfisk med vekt på kystnære farvann. En undersøkelse av innholdet av dioksiner og dioksinlignende PCB i torskelever fra 15 fjorder og havner langs norskekysten [Norwegian]. NIFES report 9th of February 2011.

Okey, A. B. (1990). Enzyme induction in the cytochrome P-450 system. Pharmacology \& Therapeutics, 45, 241-298.

Pacini, N., Abate, V., Brambilla, G., De Felip, E., De Filippis, S. P., De Luca, S., di Domenico, A., D’Orsi, A., Forte, T., Fulgenzi, A. R., Iacovella, N., Luiselli, L., Miniero, R., \& Iamiceli, A. L. (2013). Polychlorinated dibenzodioxins, dibenzofurans, and biphenyls in fresh water fish from Campania Region, southern Italy. Chemosphere, 90, 80-88.

Pandelova, M., Henkelmann, B., Roots, O., Simm, M., Järv, L., Benfenati, E., \& Schramm, K. W. (2008). Levels of PCDD/F and dioxin-like $\mathrm{PCB}$ in Baltic fish of different age and gender. Chemosphere, 71, 369-378.

Papadopoulou, E., Caspersen, I. H., Kvalem, H. E., Knutsen, H. K., Duarte-Salles, T., Alexander, J., Meltzer, H. M., Kogevinas, M., Brantsæter, A. L., \& Haugen, M. (2013). Maternal dietary intake of dioxins and polychlorinated biphenyls and birth size in the Norwegian Mother and Child Cohort Study (MoBa). Environmental International, 60, 209-216.

Parera, J., Abalos, M., Santos, F. J., Galceran, M. T., \& Abad, E. (2013). Polychlorinated dibenzo-p-dioxins, dibenzofurans, biphenyls, paraffins and polybrominated diphenyl ethers in marine fish species from Ebro River Delta (Spain). Chemosphere, 93, 499-505.

Persson, N. J., Gustafsson, O., Bucheli, T. D., Ishaq, R., Naes, K., \& Broman, D. (2002). Soot-carbon influenced distribution of $\mathrm{PCDD} / \mathrm{Fs}$ in the marine environment of the Grenlands fjords, Norway. Environmental Science \& Technology, 36, 4968-4974.

Piskorska-Pliszczynska, J., Maszewski, S., Warenik-Bany, M., Mikolajczyk, S., \& Goraj, L. (2012). Survey of persistent organochlorine contaminants (PCDD, PCDF, and PCB) in fish collected from the Polish Baltic fishing areas. Scientific World Journal 2012 Article id 973292

Poland, A., \& Knutson, J. C. (1982). 2,3,7,8-Tetrachlorodibenzop-dioxin and related halogenated aromatic hydrocarbons: examination of the mechanism of toxicity. Annual Review of Pharmacology and Toxicology, 22, 517-554.

Rosseland, B.O., Massabuau, J. C., Grimalt, J., Hofer, R., Lackner, R., Raddum, G., Rognerud, S., \& Vives, I. 2001. Fish ecotoxicology, The EMERGE fish sampling manual for live fish. The EMERGE Project (European Mountain lake Ecosystems: Regionalisation, diaGnostic and socio-economic valuation).

Safe, S. H. (1994). Polychlorinated biphenyls (PCBs): environmental impact, biochemical and toxic responses, and implications for risk assessment. Critical Reviews in Toxicology, 24, 87-149.

Schoeters, G., Goyvaerts, M. P., Ooms, D., \& Van Cleuvenbergen, R. (2004). The evaluation of dioxin and dioxin-like contaminants in selected food samples obtained from the Belgian market: comparison of TEQ measurements obtained through the CALUX bioassay with congener specific chemical analyses. Chemosphere, 54, 1289-1297.

Scippo, M. L., Eppe, G., De Pauw, E., \& Maghuin-Rogister, G. (2004). R-CALUX((R)) screening of food samples: evaluation of the quantitative approach to measure dioxin, furans and dioxin-like PCBs. Talanta, 63, 1193-1202.
Stronkhorst, J., Leonards, P., \& Murk, A. J. (2002). Using the dioxin receptor-CALUX in vitro bioassay to screen marine harbor sediments for compounds with a dioxin-like mode of action. Environmental Toxicology and Chemistry, 21, 25522561.

Struciński, P., Piskorska-Pliszczyńska, J., Maszewski, S., Góralczyk, K., Warenik-Bany, M., Mikołajczyk, S., Czaja, K., Hernik, A., \& Ludwicki, J. K. (2013). PCDD/Fs and DLPCBs intake from fish caught in Polish fishing grounds in the Baltic Sea-characterizing the risk for consumers. Environmental International, 56, 32-41.

Szlinder-Richert, J., Barska, I., Usydus, Z., Ruczyńska, W., \& Grabic, R. (2009). Investigation of PCDD/Fs and dl-PCBs in fish from the southern Baltic Sea during the 2002-2006 period. Chemosphere, 74, 1509-1515.

Van den Berg, M., Birnbaum, L., Bosveld, A. T., Brunström, B., Cook, P., Feeley, M., Giesy, J. P., Hanberg, A., Hasegawa, R., Kennedy, S. W., Kubiak, T., Larsen, J. C., van Leeuwen, F. X., Liem, A. K., Nolt, C., Peterson, R. E., Poellinger, L., Safe, S., Schrenk, D., Tillitt, D., Tysklind, M., Younes, M., Waern, F., \& Zacharewski, T. (1998). Toxic equivalency factors (TEFs) for PCBs, PCDDs, PCDFs for humans and wildlife. Environmental Health Perspectives, 106, 775-792.

Van den Berg, M., Birnbaum, L. S., Denison, M., de Vito, M., Farland, W., Feeley, M., Fiedler, H., Hakansson, H., Hanberg, A., Haws, L., Rose, M., Safe, S., Schrenk, D., Tohyama, C., Tritscher, A., Tuomisto, J., Tysklind, M., Walker, N., \& Peterson, R. E. (2006). The 2005 World Health Organization reevaluation of human and mammalian toxic equivalency factors for dioxins and dioxin-like compounds. Toxicological Sciences, 93, 223-241.

van Leeuwen, S. P., Leonards, P. E., Traag, W. A., Hoogenboom, L. A., \& de Boer, J. (2007). Polychlorinated dibenzo-p-dioxins, dibenzofurans and biphenyls in fish from the Netherlands: concentrations, profiles and comparison with DR CALUX bioassay results. Analytical and Bioanalytical Chemistry, 389, 321-333.

Villeneuve, D. L., Kannan, K., Khim, J. S., Falandysz, J., Nikiforov, V. A., Blankenship, A. L., \& Giesy, J. P. (2000). Relative potencies of individual polychlorinated naphthalenes to induce dioxin-like responses in fish and mammalian in vitro bioassays. Archives of Environmental Contamination and Toxicology, 39, 273-281.

Vromman, V., Baert, K., Vanderperren, H., Goeyens, L., André Huyghebaert, A., Maghuin-Rogister, G., Scippo, M.-L., Moons, E., Vinkx, C., Saegerman, C., \& Pussemier, L. (2012). Evaluation of the use of CALUX results for dioxins and dioxin-like PCBs analysis for quantitative human exposure assessments. Food Control, 27, 314-321.

Wania, F. (1999). On the origin of elevated levels of persistent chemicals in the environment. Environmental Science and Pollution Research International, 6, 11-19.

Wania, F., \& Su, Y. (2004). Quantifying the global fractionation of polychlorinated biphenyls. Ambio, 33, 161-168.

Zacs, D., Bartkevics, V., \& Viksna, A. (2013). Content of polychlorinated dibenzo-p-dioxins, dibenzofurans and dioxin-like polychlorinated biphenyls in fish from Latvian lakes. Chemosphere, 91, 179-186. 